Daniel Weidner · Sigrid Weigel (Hg.)

Benjamin-Studien 3 

Daniel Weidner · Sigrid Weigel (Hg.)

Benjamin-Studien 3

Wilhelm Fink 
Die Drucklegung dieses Werkes wurde unterstützt mit den Mitteln des Bundesministeriums für Bildung und Forschung unter den Förderkennzeichen 1UG0712 und 01UG1412.

Bibliografische Information der Deutschen Nationalbibliothek

Die Deutsche Nationalbibliothek verzeichnet diese Publikation in der Deutschen Nationalbibliografie; detaillierte bibliografische Daten sind im Internet über http://dnb.d-nb.de abrufbar.

Alle Rechte, auch die des auszugsweisen Nachdrucks, der fotomechanischen Wiedergabe und der Übersetzung, vorbehalten. Dies betrifft auch die Vervielfältigung und Übertragung einzelner Textabschnitte, Zeichnungen oder Bilder durch alle Verfahren wie Speicherung und Übertragung auf Papier, Transparente, Filme, Bänder, Platten und andere Medien, soweit es nicht $\$ \$ 53$ und 54 UrhG ausdrücklich gestatten.

(C) 2014 Wilhelm Fink, Paderborn

(Wilhelm Fink GmbH \& Co. Verlags-KG, Jühenplatz 1, D-33098 Paderborn)

Internet: www.fink.de

Lektorat: Bettina Moll, Berlin; www.texttiger.de

Satz: Tilo Lothar Rölleke, Berlin

Einbandgestaltung: Evelyn Ziegler, München

Printed in Germany

Herstellung: Ferdinand Schöningh GmbH \& Co. KG, Paderborn

ISBN 978-3-7705-5782-0 


\section{BRIAN BRITT}

\section{Identity and Survival in Deutsche Menschen}

The flourishing of literature and thought during the age of Goethe may have inspired German nationalism in the 1930s, but Walter Benjamin identified other values in the period worth defending. Deutsche Menschen is a short collection of edited letters by well-known German authors which Benjamin published in 1936 under the pseudonym Detlef Holz in order to hide his Jewish identity. In his inscription to Scholem's copy of the book, Benjamin wrote, "May you, Gerhard, find a chamber in this ark - which I built when the Fascist flood started to rise for the memories of your youth, " and in his sister's copy Benjamin wrote, "This ark, built after a Jewish model, for Dora - From Walter.«1

This essay considers what Benjamin may have meant by those inscriptions. Looking beyond discussions of "German, « "Jewish, « and even "German-Jewish" identity, this essay explores Benjamin's descriptions of his letter collection, asking how he conceptualized and framed it at first and how it may have changed between 1931 and 1936. The categories of tradition and agency will be my focus, which I will develop in the context of Benjamin's other writings and his particular interests in quotation and materialism. The formation and reception of Deutsche Menschen reveal a complex, ambitious project that combines many of Benjamin's ideas and goals.

Benjamin's collection began as an occasional series of letters he collected and published in the Frankfurter Zeitung in 1931-1932, the end of the Weimar Republic. In its final, book form, Deutsche Menschen includes twenty-five letters by, to, and about famous German writers and scientists on topics of death, friendship, love, and other realities of life, including personal finances. Kant, Goethe, Hegel, Schleiermacher, Nietzsche, and Grimm are among the authors and subjects of the letters, which Benjamin introduced with short commentaries that contextualize and appraise the letters in the moralizing terms of the book's dedication: „From Honor without Fame/ From Greatness without Glamor/ From Dignity without Pay« („Ehre ohne Ruhm, Größe ohne Glanz, Würde ohne Sold«, GS IV, 150).

The stated purpose of the collection is to depict a lost cultural age (1783-1883): "It was the age when the German bourgeoisie had to place its weightiest and

1 Gershom Scholem: Walter Benjamin. The Story of a Friendship, trans. Harry Zohn, New York (Schocken) 1981, p. 202. A similar inscription appears in Siegfried Krakauer's copy. See Erdmut Wizisla: »Plaquette für Freunde`, Widmungen für den Leser«, in: Barbara Hahn/Erdmut Wizisla (eds.): "Walter Benjamins `Deutsche Menschen«", Göttingen (Wallstein) 2007, pp. 45-67. I wish to thank Dr. Wizisla for his consultation on this essay. 
most sharply etched words on the scales of history. And it had little to place there except those words." Benjamin marks the transitions of this period by Goethe's 1825 lament over the rise of modern technology and mediocrity: „We may be the last representatives - with a few others perhaps - of an era that will not easily come again" (SW III, 167). This passage could be construed as a straightforward expression of nostalgia, but in light of the complexity of Deutsche Menschen and Benjamin's use of the quotation here and elsewhere (in a playful radio play and a leftist encyclopedia article), I believe the quotation serves rather to criticize contemporary Germany in ways that have little to do with Goethe's text.

Benjamin had great ambitions for his book. In his letters and manuscripts he says he seeks to reach a large audience in Germany with "a kind of golden library of classics in nuce (GS IV, 949). He envisions a book with wide appeal to school children, professors, journalists, and others that combines the elements of popular anthology, scholarly edition and a classic edition (950). This would be a large (double-sized) volume, like what people now call a coffee-table book (948-949). Whatever Benjamin intended with Deutsche Menschen, he wanted it to reach a large public.

At first Deutsche Menschen looks more like a veneration of German letters written out of nostalgia or economic necessity than a major theoretical statement, but a closer look reveals a project that began with newspaper articles and became a book that reflects Benjamin's thinking about cultural traditions and practices of quotation. When he began the project in 1931, it seems unlikely that Benjamin set out to write a personal manifesto on the legacy of German letters, much less to build a Jewish ark against the Fascist flood, but by 1936 he had achieved something that strikingly draws a number of his interests together. What I wish to pose as a question here is how Deutsche Menschen balances some of these interests, particularly one that will be familiar to many readers of Benjamin, the commitment to the power of words, literature, and literary culture on the one hand and a rather different commitment to a materialist critique of fascism on the other.

Benjamin's dedication of the book as an "Ark» (Arche), notes Erdmut Wizisla, is only for Jewish recipients: his sister, Siegfried Kracauer, and Scholem. ${ }^{2}$ So what did Benjamin mean by the Noah's Ark reference in the dedications to Scholem, Kracauer, and his sister? How does he understand the biblical story? Is Deutsche Menschen an esoteric Jewish text? The question, of course, has sectarian implications - if Benjamin's text has a secret meaning reserved only for Scholem, his sister, and Kracauer, it stands to be lost even on Adorno, whom Benjamin still addresses as »Sie« in letters from this time. I raise the question partly to note the

2 Wizisla: »Plaquette für Freunde« (note 1), p. 61. 
frisson of esotericism that runs not only through some of Benjamin's writings but through much scholarship on Benjamin as well.

There can be no simple resolution to the question of Jewish-German identity in Benjamin's thought, though some boundaries around the problem can be delineated. It is safe to say, for example, that Judaism and Jewish identity are not limited for Benjamin to halakhic observance; in fact, Benjamin had little direct knowledge or experience of traditional Jewish life or Hebrew texts, and his main source of knowledge about Judaism, Gershom Scholem, famously pursued the study of esoteric texts and traditions rather than traditional Jewish practices. As for German literary culture, one can also say with confidence that Benjamin was keenly sensitive to the ethnic and nationalistic politics associated with German letters. It would be just as difficult to mark Benjamin as a "melting-pot" pluralist who believed that Kantian principles of human dignity and equality could somehow be trusted to protect against the kinds of danger that he recognized in the language and culture around him even before the rise of National Socialism. Benjamin's clarity about the limitations of these three positions does not, unfortunately, add up to a systematic or compelling resolution to the question of identity. Instead, a crucial if modest gesture of Benjamin's work on this problem is a sustained commitment to attentiveness, disciplined perception, and self-awareness.

What is more, Benjamin's text was public from the beginning, and while it implies more than it says about politics, its distance from fascism and even modern nationalism is clear. And for all the evidence of esoteric intent, there is just as much to be said for Benjamin's public ambitions for the book and its development from newspaper articles. But the dedications reveal an interpretive frame for the project that likely became clearer to Benjamin between 1931 and 1936. This essay sketches a reading of Deutsche Menschen with these dedications as a kind of guide. There is a tendency to read Benjamin's text as a forceful repudiation on Nazi ideology, and to sentimentalize it. ${ }^{3}$ The main problem with this

3 This is something on which Scholem and Adorno agree. Cf. Adorno's "Nachwort«, in: Theodor W. Adorno: Noten zur Literatur, ed. by Rolf Tiedemann, Frankfurt a. M. (Suhrkamp) 2003, pp. 686-692, where he describes the motto of the book as "oppositionell« (p. 686), a defense of the values destroyed by Nazis (p. 687), and the book as "Denkmal« of this lost world that shows how far it is (»lehrt die Distanz von ihnen« [p. 692]). Scholem: Walter Benjamin (note 1), p. 203. Recent versions of this view can be found in Axel Schmitt: "Schiffbruch", literaturkritik.de (2004) 6 (online available at: www.literaturkritik.de/public/rezension/php?rez_id=7151, accessed March 19, 2014) and Albrecht Schöne: "Diese nach jüdischem Vorbild erbaute Archer. Walter Benjamins ,Deutsche Menschen«", in: Stéphane Moses/Albrecht Schöne (eds.): Juden in der deutschen Literatur. Ein deutsch-israelisches Symposion, Frankfurt a. M. (Suhrkamp), 1986, pp. 350-365. 
view is that it overlooks the scope of this project, which began well before 1931 and relates to several other writing projects, some of which are discussed here. My claim is that we can discern many of Benjamin's abiding commitments in Deutsche Menschen - humanism, romanticism, critique of progress, materialism (but no mention of Judaism!) - and that its "text-and-commentary" structure reflects traditional literary scholarship and anticipates the quotationbased method he devised and implemented later in his Arcades Project.

\section{Structure and Design}

Several separate texts on this project appear in Benjamin's Gesammelte Schriften, including one from 1931-1932 when the letters appeared in the Frankfurter Zeitung, a possible radio address called "On the Trail of Old Letters." Here Benjamin adopts a genial, scholarly voice and places emphasis on the "humanity" and "living tradition" (»lebendige Überlieferung «) conveyed by the letters (GS IV, 944). He presents the letters as neglected and overlooked classics that deserve a place in the literary canon, along with a way of reading these letters not "to underpin a cult of the writer as hero" but to credit the humanity of the writers as "noble, creditable, and rich in substance" through "something that facilitates communication with his lesser contemporaries" (SW II, 556-557). In this retrieval of the overlooked, non-canonical, and ordinary documents of life, with its challenge to conventional literary scholars about the value and meaning of letters and the canon, Deutsche Menschen resembles the materialist aesthetic of Benjamin's later essay on the collector Edward Fuchs (1937). Any full-blown materialist reading of the text, then, would be an alternative to the emphasis on Jewish identity suggested by Scholem and Wizisla.

A second, probably later, text called "German Letters« takes a more political tone, suggesting that the language of "secret Germany" (ein geheimes Deutschland) and "civic duty in an emergency" (Aufruf der bürgerlichen Not). This text includes three letters on political subjects by Forster, Hölderlin, and Seume, of political nature, including the French and American revolutions (GS IV, 946-947). This theme of emergency is echoed in a letter from 1932 in which he cites the project as one of several that deal with sites of rubble or catastrophe (»die die eigentliche Trümmer- oder Katastrophenstätte bezeichnen«, 947).

Benjamin originally ended Deutsche Menschen with an angry farewell letter from Schlegel to Schleiermacher, but just as the book was about to be published he decided to remove it because of its "negative content" and »lesser weightiness," 
making the number of letters twenty-five instead of twenty-six. ${ }^{4}$ It is not clear why the letter was reintroduced in the 1962 edition of Deutsche Menschen, but it was apparently Adorno's idea. He wrote to the editor of the 1962 edition suggesting that the letter be added, saying that he found this letter in the Frankfurter Zeitung and that it was missing from the book for some reason, "vielleicht nur der glatten Zahl 25 zuliebe." Later, the editors of Benjamin's Gesammelte Schriften included this letter as an "Anhang." The final letter now became the letter from Overbeck to Nietzsche; Benjamin's introduction to this letter mentions theology and Christianity frequently, and it tellingly ends as follows:

True Christianity, for him, meant an absolute, eschatologically founded denial of the world. Acceptance of the world and its culture was a repudiation of Christianity's essence, and all theology from the patristic period onward was a Satan among religions. Overbeck was aware that he had "written himself out of Germany as a theology teacher." Here is the letter, whose recipient had voluntarily exiled themselves from the Germany of the Gründerzeit. (SW III, 217) ${ }^{6}$

An undated typescript collected with Benjamin's notes for the project includes headings for grouping the letters: "Schule und Leben, "Neue Gesichtspunkte, » Der Verfall und die Reichsgründung, »Publikationsfehler, »Vorbildliche Editionen, "Briefe, die Klüfte erhellen wie Blitze,« and "Falsche Klassizität«. (WuN X, 123-124) Although this list does not appear to govern the final version of Deutsche Menschen, it reveals Benjamin's diverse literary and social-historical goals for the project.

4 »Ich könnte mir denken, daß Sie mit mir der Meinung sind, dies sei keine ansprechende Zahl. Zu dieser Überlegung würde sich dann meine Wahrnehmung fügen, daß der Brief von Schlegel an Schleiermacher sowohl seinem negativen Gehalt wie seinem minderen Gewicht nach keine ganz glückliche Figur macht" (GB V, 377). Cf. Michael Diers: „Einbandlektüre, fortgesetzt. Zur politischen Physiognomie der Briefanthologie«, in: Hahn/Wizisla (eds.): "Deutsche Menschen« (note 1), pp. 24-29, which makes the best argument for the political aims of the book, even down to lettering, title, and design. Broderson goes on to note that the letter was added back in to the posthumous 1962 edition (in the middle, after Hölderlin's letter) with an afterword by Adorno, noting that it was left out of a later edition and added as an "Anhang" (WuN X, 313).

5 Adorno to Siegfried Unseld, 11 January 1962, in: Wolfgang Schopf (ed.): „So müßte ich ein Engel und kein Autor sein «. Adorno und seine Frankfurter Verleger, Frankfurt a. M. (Suhrkamp) 2003, p. 399. Unseld agreed with Adorno wholeheartedly, noting that it was a "very beautiful letter" and that Benjamin's commentary »develops a good image (»Unseld to Adorno, 12 January 1962«, ibid., p. 401).

6 Adorno to Siegfried Unseld, 11 January 1962, in: Schopf (ed.): "So müßte ich ein Engel und kein Autor sein" (note 5), p. 399. Unseld agreed with Adorno wholeheartedly, noting that it was a "very beautiful letter" and that Benjamin's commentary "develops a good image" (»Unseld to Adorno, 12 January 1962«, ibid., p. 401). 


\section{Commentary, Quotation, and Agency}

Commentary and quotation constitute the two main elements of Deutsche Menschen, and by themselves their purpose seems fairly straightforward: to inform the public about interesting letters by well-known German authors of the past. But commentary and quotation are important categories in Benjamin's thought, linked to his understandings of aesthetic and political agency. ${ }^{7}$ For Benjamin, commentary gives life to works, and along with translation, constitutes their afterlives. He considers commentary, which "takes for granted the classical status of the work under discussion, « to be as constitutive of a work as the "seasonally falling fruits on a tree. ${ }^{8}$ Given his shift from traditional texts to the material culture of modernity in the Arcades Project, Deutsche Menschen can easily be seen as a relic of an earlier intellectual paradigm. But in the methodological notes to the Arcades Project, Benjamin explicitly related the two kinds of work: "The expression the book of natures indicates that one can read the real like a text. And that is how the reality of the 19th century will be treated here. We open the book of what happened" (Arcades, 464). Nevertheless, the "commentary on a reality « will differ from textual commentary: »In the one case, the scientific mainstay is theology; in the other case, philology" (460). No explanation of this distinction follows, but the place of theology in the ostensibly materialist study of 19th-century culture echoes other affirmations of religious tradition in Benjamin's late work as a companion to materialist analysis.

Of course, the opposition between theology and philology is artificial and alien to Benjamin's work, just like the distinction between tradition and modernity or religion and secularity. What is crucial here is to see how Deutsche Menschen mixes Benjamin's interests just as richly as the Arcades Project. Its appearance as a traditional celebration of belles lettres accompanies decidedly political and materialist interests. The letters in Deutsche Menschen concern ordinary life, personal finances, friendship, and death, and they are presented in a conversational tone that extols the values of a bygone era marked by Goethe and the Biedermeyer, but Benjamin's commentaries challenge nationalistic and triumphalist canons of German literature and thought.

The idea that quotation by itself can be a powerful form of critical expression has been noted and discussed by a wide range of scholars.' In this vein, I suggest

7 See Benjamin Sax: „Walter Benjamin’s Karl Kraus. Negation, Quotation, and Jewish Identity«, in: Shofar 32.3 (2014), pp. 1-29.

8 Walter Benjamin: "Commentary on Poems by Brecht«, in: SW IV, 215-250, here 215, and id.: One-Way Street, in: SW III, 443-488, Harold Bloom: The Anxiety of Influence. A Theory of Poetry, London (Oxford University Press) 1973.

9 Cf. e. g., Manfred Voigts: »Die Mater der Gerechtigkeitヶ. Zur Kritik des Zitat-Begriffes bei Walter Benjamin«, in: Norbert W. Bolz/Richard Faber (eds.): Antike und Moderne. Zu Walter Benjamins "Passagen«, Würzburg (Könighausen \& Neuman) 1986, pp. 97-115 and Eli Friedlander: Walter Benjamin. A Philosophical Portrait, Cambridge (Harvard University Press) 2012. 
that Benjamin's methods of quotation have modern sources like montage and the essays of Karl Kraus along with roots in biblical and Jewish tradition. Based on how Benjamin talks about quotation in the Arcades Project, it was a technique that could serve materialist critical ends (though Adorno doubted its potential). The question I find most interesting about Benjamin's description of Deutsche Menschen as a Jewish ark is thus not the familiar debate on German versus Jewish identity, for in Benjamin's case I don't see how we can ever get beyond the hyphen in "German-Jewish." What interests me more is whether and how the kind of quotation and commentary he performs here can signify a kind of political agency. This is where I find my uncertainty, between the skepticism of Adorno and the conviction of Benjamin that this kind of project matters in a political and not merely literary sense.

It seems to me there are two important stakes in this question about Deutsche Menschen that resonate with contemporary political and cultural theory. One, very bluntly, is what beyond bare life is worth living and fighting for. For Benjamin, the question was pressing (not just in a personal way); he had already sharply dismissed neo-Kantian ideals of human rights based on mere life in his "Critique of Violence, " and his distance from orthodox Marxism likewise shows he cares about more than economic justice. Now he faced a crisis, one that unfolded during the years this project progressed: could the ideals of German culture be salvaged under German nationalism and fascism? Deutsche Menschen, which begins with a letter mourning the death of Goethe and includes four more on death and mourning, does not tell us directly, and the inscriptions only complicate matters by speaking of a Jewish ark. A second, related question is: If these ideals are worth fighting for, how one do so without resorting to nostalgia, outdated literary standards, or nationalism?

In order to overcome the risks of esoteric politics and sentimental nostalgia, Benjamin's project needed not only to reach the German public, which was his great wish; but it also had somehow to convey the meaning he intended for it during a time of danger. What Benjamin offers is a strong reading of the Romantic era as a rejection of its later nationalistic appropriations. He openly cites Lukacs; ${ }^{10}$ honors the values of labor, cosmopolitanism, and humanism, and criticizes political, economic, and jingoistic tendencies of the past and present. ${ }^{11}$ A second, more fundamental risk is the tension between materialist and linguisticaesthetic commitments in the essay. Attention to material life, privation, and

10 »Georg Lukacs made the far-sighted observation that the German bourgeoisie had not yet wrested its first opponent - feudalism - to the ground by the time its last opponent - the proletariat - already stood before it« (SW III, 212, in introduction to Metternich letter).

11 Cf., e. g., the introduction to the letter by Forster (p. 173), and the introduction to the Clodius letter (p. 188), introduction to Liebig (pp. 195-196). 
decoration (Biedermeyer) contrasts the elevation of language and linguistic art as intrinsically valuable, even transcendent. The analogy between the aesthetics of Schiller and the middle-class interior (including a bust of the poet) as an asylum for those values is about as close as Benjamin comes to reconciling his materialist and aesthetic-idealist perspectives. From the standpoint of the literary frame, where catastrophe looms behind the image of the ark built to withstand the rising fascist flood, the gesture seems more noble but just as fragile. But is there any alternative?

Scholem certainly thought Benjamin's inscription indicated an affirmation of the power of writing in Jewish tradition; he comments: "Just as the Jews took refuge from the persecutions in the Writ, the canonical book, Benjamin's own book constitutes a saving element fashioned after the Jewish prototype. ${ }^{12}$ The paradox of this example is that Benjamin's text, a celebration of the "secular," gentile tradition of German letters, elicits one of the most explicitly biblical passages in Scholem's book on Benjamin. It is also important not to forget the gentile pseudonymous author of the text, Detlef Holz, whose name is signed in a different copy of the book - inscribed to dedication to his friend, the drug researcher Fritz Fränkel - with the flamboyantly crossed "t" and "f.."13 The book's appeal to human agency may be feeble, but it appeals to the kind of paradoxical synthesis - a »secular," gentile work helping to preserve biblical, Jewish tradition that history was unable to achieve.

The pseudonym points to a further problem with Benjamin's Jewish reading and its affirmation by Scholem: Christianity. There are several very Christian obstacles to those who want to read Deutsche Menschen simply as an affirmation of Jewish identity. Benjamin introduces the final letter (Overbeck to Nietzsche) by invoking "true Christianity" (SW III, 217). The letter from Johann Heinrich Voss to Jean Paul celebrates the coincidence of Christmas and reading Shakespeare in the author's childhood, while Strauss' letter describes Hegel as Christlike (190; 204).

Discussion of the underlying meaning of Deutsche Menschen has dominated the book's reception, beginning with Benjamin himself. In an essay on the handwritten dedications to Deutsche Menschen, Benjamin archivist Erdmut Wizisla argues that Benjamin hid messages in this text as in Einbahnstrasse: "The collection betrays the handwriting of the editor. [...] It is a >Plaquette für Freunde. $\|^{14}$ The dedication of the book as an "Ark« (Arche), notes Wizisla, is

12 Scholem: Walter Benjamin (note 1), S. 203.

13 Wizisla: »Plaquette für Freunde« (note 1), p. 55.

14 Ibid., p. 52. 
only for Jewish recipients: his sister, Siegfried Kracauer, and Scholem..$^{15}$ Erich Auerbach recognized the political implications of the book, wondering in a letter to Benjamin whether it could be ordered or sent to Germany. ${ }^{16}$ Scholem worried that it would be banned by Hitler because his commentary was "unmistakably corrupting. ॥ $^{17}$

\section{Mourning and/or Melancholia}

Deutsche Menschen is preoccupied with mourning and presents several ways of relating the lost past to the present: intimacy, afterlife, nostalgia, and eternal recurrence. The collection begins with a letter from composer Karl Friedrich Zelter suggesting the death of his friend Goethe will somehow bring them closer: "Now that he has passed on before me, I draw closer to him daily" (SW III, 168). A later letter from Goethe expresses condolences to the son of a scientist with whom he had profound disagreements. Benjamin dedicates several pages of close exegetical analysis to that letter, something he does nowhere else, and rarely in any of his work. Quoting short phrases from the letter, Benjamin attaches historical and biographical significance to its language and diction: "Like him, his language stood at a frontier" (205). Of the phrases »out life as it rushes past« and "turbulent and crowded,"Benjamin says that Goethe "makes it abundantly clear that the writer has withdrawn contemplatively to [life's] shore" (206). Mourning is the focus of two other letters, including an effusive letter by David Friedrich Strauss on the death of Hegel, the introduction of which points to "a revolutionary and unforeseen kind of afterlife [»Art des Fortlebens"] « at the funeral (202; GS IV, 205). Benjamin's earlier citation of Goethe in the Foreword mourns the loss of an era he typified: "an era that will not easily come again [»wiederkehrt»]« (167; GS IV, 151). But nostalgia is not the only way Deutsche Menschen relates past to present. Benjamin's introduction to Metternich's letter about the Crimean War speaks of the »eternal recurrence« (ewigen Wiederkunft) of contradictions between political words and actions (222).

Echoing Goethe's sentiments about a lost age, Adorno's "Afterword" to a 1962 edition associates the entire collection with mourning, describing it as a

15 Ibid., p. 61.

16 Letter from Auerbach to Benjamin, 28 January 1937, in: Karlheinz Barck: "5 Briefe Erich Auerbachs an Walter Benjamin in Paris«, Zeitschrift für Germanistik 6 (1988), pp. 688-694, here pp. 691 and 694, quoted in: Wizisla: $m$ Plaquette für Freunde« (note 1), p. 64.

17 Letter of 1 March 1937, in: Gershom Scholem (ed.): The Correspondence of Walter Benjamin and Gershom Scholem 1932-1940, trans. Gary Smith/Andre Lefevere, New York (Schocken) 1989, p. 192, quoted in: Wizisla: »Plaquette für Freunde» (note 1), p. 64. 
memorial (Denkmal) to the lost world and values destroyed by the Nazis. ${ }^{18}$ For Adorno as for Benjamin (and Goethe), the loss of a past era provides critical perspective on the present, despite their nostalgic tone. Like the use of melancholy in his study of the Trauerspiel, the focus on mourning in Deutsche Menschen activates critical possibilities for reflection not only on who is lost but on what is lost, namely, principles such as the epigraph's honor, greatness, and dignity.

\section{Text as Ark: Asylum, Detlef Holz, Miniatures, the Biedermeier, and the Challenge of Materialism}

Benjamin's designation of his book as a Jewish ark poses not just the question of what is Jewish about this very German, Christian-looking work; is also suggests associations between the catastrophe of Nazism and the biblical story of the Flood, particularly the purpose and effect of the book as an ark. Beginning with Scholem, some readers have accordingly categorized the book as a thoroughly Jewish work of commentary in the tradition of Midrash and Talmud. ${ }^{19}$ The purpose of this commentary, for Scholem at least, is no less than the performance of rescue or redemption (retten) through scripture (cited in Schmitt). The ark, suggests Schmitt in a clever turn of phrase, thus becomes "Arche-écriture which gestures toward a restored, messianic language and Scripture. If the book is an ark, then it can be seen as a mobile space for cultural memory, one that evokes continuity as well as rupture (Schmitt).

The ark, of course, is made of "cypress wood" (»Tannenholz«, Gen 6:14), which echoes Benjamin's pseudonym "Holz« (wood). ${ }^{20}$ But it would be a mistake to suggest that Benjamin attempts anything like a close reading of the biblical story. His dedication uses the term "Arche« instead of the biblical »Kasten, « and the only commentary in Deutsche Menschen applies to the letters themselves. Yet there is clearly something significant in Benjamin's reference to the Flood story. The paired letters, for instance, can be compared to the pairs of animals in the ark. Detlev Schöttker, who makes this point, notes Benjamin's view that commentary emerges from the classic status of the text and suggests the goal

18 Adorno: Noten zur Literatur (note 3), pp. 687 and 692.

19 Cf. Schmitt: »Schiffbruch« (note 3).

20 Note also that "Detlef« and "Deutsch" are etymologically related to an Indo-European root meaning 'peopler (thanks to Stephen Britt for this observation). The title Deutsche Menschen, along with the pseudonym "Detlef» thus emphasizes the humanity, not the particular ethnic identity, of the "Germans». 
of the ark is "to secure the long-term survival of the types through the rescue of pairs. $\aleph^{21}$

The importance of material culture to Benjamin - toys, art, books, and cityscapes - is no secret. But how to understand these preoccupations is not as clear. Like his interest in religion, these concerns for minute details of material reality can easily be dismissed as peccadillos or obsessions of a sentimentalist. They can also be magnified in a melodramatic fashion to mean more than they do. Benjamin's "Biedermeier" letter (from Clodius to von der Recke) appeared in 1931 and contains a number of key terms and topics that link it to the "Arche." My main point here is that the domain of miniatures - the puppet, doll house, children's toy - is crucial to Benjamin, as others have shown. ${ }^{22}$ For Benjamin as for many people today, Noah's ark evokes childhood and childhood toys. The term "Arche« appears only rarely in Benjamin's writings, but its most frequent association is with toys and wooden figures (GS III, 113; 126, and GS IV, 422). The ark Benjamin describes having built in his text thus carries the associations of a toy, a miniature. That doesn't diminish its seriousness, but it does place a high premium on a particular aesthetic one can find throughout Benjamin's work and that biographers might link to his childhood growing up around the collectibles of his family business.

Like »ark" (Arche), the term Biedermeier in Benjamin also evokes toys, but it has another association as well: the period of the emergence of the German middle class in the early 19th century, in this case particularly with respect to miniature versions of furnished interiors. Benjamin's remarkable commentary compares the Biedermeyer toy exhibit in the Louvre, which included decorative busts of Shakespeare, Tiedge, and Schiller, to Schiller's aesthetics: »However brutally the aesthetic play - the play through which the Briefe über die äesthetische Erziehung des Menschen sought to educate free citizens - was interrupted on the historical stage, it found a safe refuge $[A s y l]$ in those middle-class rooms which could so closely resemble dollhouses" (SW III, 188). In other words, the domain of aesthetics (in Schiller's letters) gained refuge against danger in the dollhouse-like middle class rooms depicted in the Louvre (ibid.).

The inversion here is fascinating: dollhouses in France resemble German middle-class interiors, and the interiors in turn resemble dollhouses, making them a refuge $(A s y l)$ for aesthetic freedom. Benjamin's interest in miniatures, suggests

21 Detlev Schöttker: Konstruktiver Fragmentarismus, Frankfurt a. M. (Suhrkamp) 1999, p. 98 (Ilit Ferber made a similar comment [personal communication, January 2012]). Cf. Jacques Derrida: Fichus: Frankfurter Rede, trans. Stefan Lorenzer, Wien (Passagen) 2003, where Derrida plays with the »D« of his dream, described in a letter to Gretel Adorno (signed Detlef), about a scarf in the shape of this letter (pp. 29-31).

22 Friedlander: Walter Benjamin (note 9), p. 5, 260, n. 23. 
Friedlander in reference to the Trauerspiel study, deploys his theory of monads to "concentrate a dimension of infinity and produce a sense of its realization. $\aleph^{23}$ The spatial monad, such as the Paris Arcade, represents the entire 19th-century universe, and the temporal monad summarizes all of history. What is more, the monad reveals the potential for change and thus a kind of agency: "If the object of history is to be blasted out of the continuum of historical succession, that is because its monadological structure demands it. [...] It is owing to this monadological structure that the historical object finds represented in its interior its own fore-history and after-history (Arcades, 475). Through a dialectical process, therefore, the miniature and monad uncover what may be called the power of fragility, even in the case of toy furniture.

The flood against which the ark is built appears not only in the dedications but also in a passage of Deutsche Menschen that extols the values and material conditions of the lives it represents:

They [spiritual sources] live not only on the great passions from which spring seed and blood, and still less on the influencess so often invoked, but also on the seat of daily toil and the tears which flow from enthusiasm: drops soon lost in the flood (Strom, not the biblical »Sintflut« of the dedications). (SW III, 190)

\section{Camouflage Text}

Benjamin clarified the purpose of Deutsche Menschen in a letter to Scholem, 18.10.1936, as follows: "nur aus dem Interesse, die Sammlung die vielleicht in Deutschland einigen Nutzen Stiften könnte, zzu tarnen ‘ [in the original text in bold], zu erklären ist" (GB V, 402). The same notion of "camouflage" (Tarnung) describes Deutsche Menschen in an unpublished letter from Adorno to Susanne Thieme (widow of Karl) upon learning that her husband had not suggested the title »Deutsche Menschen«:

Der Titel "Deutsche Menschen« war seinerzeit von Benjamin gewählt worden aus einem politischen Grund, nämlich um zu ermöglichen, daß das Briefbuch nach Deutschland importiert wurde, um dort oppositionell zu wirken, also als eine Art Tarnung [emphasis added], keineswegs aus Profitinteresse. Daran kann ich mich mit aller Bestimmtheit erinnern. ${ }^{24}$

23 Ibid., p. 260, n. 23; a discussion of the idea as monad appears in the Trauerspiel study: GS I, 228.

2420 September 1965, Theodor W. Adorno Archive (TWAA), Br 1534/6. 
(Adorno also described the tone of the book as »oppositional «. ${ }^{25}$ ) Benjamin rarely uses the term "Tarnung, " but it sometimes serves to indicate deceptions of capitalism (GS I, 1168, GS V, 121). He also uses the term to describe the danger of open expression in a 1933 letter to Scholem (GB II, 566). In a passage close to the theme of Deutsche Menschen, namely, the decline of "das alte Bürgertum," Benjamin describes how the bourgeoisie used the Jugendstil to conceal their own decline: "Es ist der Jugendstil[,] [...] in dem das alte Bürgertum das Vorgefühl der eignen Schwäche tarnt, indem es kosmisch in alle Sphären schwärmt und zukunftstrunken die `Jugend ‘ als Beschwörungswort mißbraucht« (GS III, 394).

The debate whether Deutsche Menschen is a Tarntext continues. Many continue to regard the text as a coded political statement against the Nazi regime, while others have begun to question this view. One of the strongest cases of the camouflage text reading is Michael Diers' study of the graphic design, publication, and context of Deutsche Menschen. Noting the resemblance of the book's typeface and title to contemporary pro-fascist books, Diers cites the importance of dissimulatio as a figure of the baroque rhetoric studied by Benjamin in the Trauerspiel study, along with his publisher's expertise in espionage. ${ }^{26}$ A skeptical rejoinder to this view is Peter Villwock's study of Deutsche Menschen, which attributes the text's recovery as a Tarntext to Adorno. This idea that Deutsche Menschen was a "Trojan horse", a camouflaged text, says Villwock, quickly became part of the German collective unconscious. ${ }^{27}$ Through a survey of the book's development and publication, Villwock identifies Benjamin's humanist interests in the original newspaper versions of the letters, particularly the emphasis on Goethe and the commemoration of the Hambach Festival, which celebrated the roots of popular democracy in Germany. ${ }^{28}$

Given its many sources, valences, and gradual development, Villwock aptly describes Deutsche Menschen as a kaleidoscope or constellation: it can be seen from many angles and variously interpreted, yet its many pieces remain distinct. Citing the reference to the Orion constellation in the letter from Wilhelm Grimm to Jenny von Droste-Hülshoff and the "weak messianic power" of $O n$ the Concept of History, Villwock goes further to claim that Benjamin uses the means of constellation and quotation to rescue splinters of German humanism from their catastrophic history. In the context of German politics in 1931, this appeal to German humanism was critical. ${ }^{29}$

25 Adorno: Noten zur Literatur (note 3), p. 686.

26 Michael Diers: »Einbandlektüre, fortgesetzt. Zur politischen Physiognomie der Briefanthologie«, in: Hahn/Wizisla: »Deutsche Menschen« (note 1), pp. 24-29, here pp. 23-24.

27 Peter Villwock: "Walter Benjamins Brief-Projekt», Auftrag des Instituts für Textkritik 13 (2012), p. 151-162, here p. 152. (Thanks to Ursula Marx for showing me this reference.)

28 Ibid., p. 158.

29 Ibid., pp. 158 and 161-162. 


\section{German Culture and the Jewish Question}

In order to clarify the purpose of Deutsche Menschen it is not only necessary to consider its origins and internal contexts. There are several related texts that resemble this text but differ in important ways from it; three I wish to discuss here are "Jews in German Culture," "What the Germans Read While their Classical Authors Wrote, « and »From Cosmopolitans to Bourgeoisie« (Vom Weltbürger zum Grossbürger). All three, like Deutsche Menschen, are purportedly designed for the education of general readers in cultural and literary traditions. Both texts shed light on how Benjamin viewed the legacy of Goethe and the roles Jews played in German culture.

"Juden in der deutschen Kultur « is an article published in the 1930 edition of the Encyclopedia Judaica: Das Judentum in Geschichte und Gegenwart. ${ }^{30}$ The article appears there with two other authors' initials: Nachum Goldmann and Benno Jacob, and Benjamin complained that the draft he submitted, now lost, was greatly shortened, and "in some places the text is neither written nor corrected by me" (GS II, 1521). This article appears only in facsimile form in Benjamin's Gesammelte Schriften (807-813) because, as the editors note, it is unclear how much of this text was Benjamin's.

The fact that we do not have Benjamin's notes or manuscripts for this encyclopedia article, and that he complained about how it was revised by editors, does limit how certain we can be that any given section is his. But I suggest that we can distinguish at least two levels of confidence about his authorship: first, the overall design of the article, which stages different kinds of encounters between Jewish tradition and German modernity with Mendelssohn at its beginning, is certainly consistent with Benjamin's interests. The next phase of this process, in which Romanticism and nationalism enter the scene, is also a familiar concern of Benjamin's; the citation of Ludwig Strauß, with whom Benjamin corresponded, is suggestive of his hand (808). Particular authors and schools also point to Benjamin, including Cohen and his students Cassirer and Rosenzweig, Georg Simmel, Rahel Varnhagen (about whom Benjamin wrote to Scholem years later [20 February 1939; GB II, 804]), and a whole list of literary figures - including Heinrich Heine, Karl Kraus, Martin Buber, Ernst Bloch, the George Circle, Hugo von Hofmannsthal - in whom Benjamin was particularly interested (811-813). At this level of design and focus, and even in the case of particular names, I think it is safe to assume Benjamin's authorial role.

A second level, of particular formulations and expressions, permits less confidence about Benjamin's authorship. Two examples bear this out: the first is a characterization of Simmel's work in relation to Jewish tradition. Here Simmel's

30 Vol. 5, 1930, cols. 1022-1034. 
work is described as an unsystematic (»systemfeindlich") psychological impressionism that can be compared to "der halachischen, seine Virtuosität in der assoziativen Verbindung zu der Exegetik und seinen Symbolreichtum zur allegorischen Bibelauslegung in Beziehung zu setzen" (810). It is unclear whether this passage is Benjamin's or the editors', but the general design of the entry and the discussion of Simmel are consistent with Benjamin's work. ${ }^{31}$ Though he knew the term "halakhah" from his conversations with Scholem years earlier, Benjamin used it mainly in his 1938 writings on Kafka and based his use on an essay by Bialik he asked Scholem to send him in 1934, four years after the encyclopedia article appeared. On the other hand, "halakhah" does appear in the Kraus essay, written around the same time as the encyclopedia entry, where Benjamin describes Kraus' work as the "most extraordinary breakthrough of halakhic writing through the mass of the German language. ${ }^{32}$ A second passage, crediting Heinrich Heine and Ludwig Börne with the creation of German »feuilletonism, « credits this style with "schrankenlose Betonung der Subjektivität; kritische Haltung gegen die professorale Wissenschaft; scharfe Belichtung aktueller Probleme« (811). If this passage reflects many of Benjamin's own interests, the discussion that follows, in which Heine's relation to Romanticism is discussed in detail, certainly does.

At first clearly distinct from Deutsche Menschen, Benjamin's »Juden in der deutschen Kultur « shares much in common with the book on which he worked soon after. Both texts concern themselves with German literary and intellectual culture from the 18th century onward. The idealism and literary culture of this epoch formed the background of Benjamin's modernism, one in which Jewish and German identity were distinct but deeply intertwined. Benjamin's self-understanding as a Jewish and German writer, especially as a critic, permeates both writings. This critical perspective is consistent with the "cultural Zionism« he claims for himself in his 1912 letter to Ludwig Strauß. Even without the "Jewish ark" dedications, we could find plenty of support in Deutsche Menschen for this kind of JewishGerman self-understanding: the values of literary and cultural criticism ascribed to Heine, for example, run through Benjamin's entire corpus, and the "secret« and "misappropriated « Germany of the manuscripts indicates something of Benjamin's intention to offer a critical and even esoteric perspective on German intellectual tradition. (WuN X, 136; 12) Finally, the »living tradition" (»lebendige Überlieferung") Benjamin finds in these texts resonates with Benjamin's understanding

31 While the exact wording of this passage cannot be definitively assigned to Benjamin, the text clearly echoes Benjamin's ideas and interests. Cf. Ubaldo Fadini: „Presentazione di un Benjamin ,Falsificato«, L'Ombra d'Argo 1 (1983), pp. 1-2, here 1.

32 Karl Kraus, "der großartigste Durchbruch des halachischen Schriftums mitten durch das Massiv der deutschen Sprache» (GS II, 624). 
not only of scriptural tradition (text and commentary) but also with the values represented by the letters (120).

What these two texts share is an unwillingness to separate German from Jewish identity in any absolute way. Readers familiar with Benjamin's Berliner Kindheit um 1900 will already recognize this pattern from Benjamin's fond description of Christmas decorations. The inscriptions on copies of Deutsche Menschen calling it a Jewish ark thus reveal not so much a hidden meaning behind the text as an abiding expression of Benjamin's self-understanding as a critic and thinker. By 1936 he may indeed have conceived of his project as a gesture of cultural and political defiance, but the fact that he adopted much of it unchanged from drafts and newspaper versions going back at least to 1931 suggests a longer view. Likewise, the "German culture" of his encyclopedia article includes contributions from Jewish writers and thinkers. In short, both texts hold "German" and "Jewish" in tension without permitting any easy separation or subordinating one to the other. Likewise, both texts insist on the robustness of cultural traditions in the face of political pressure; the politics and the aesthetics of these texts are thus inseparable.

\section{The Question of Tone: »What the Germans Read While Their Classical Writers Wrote«}

The second text is a radio play, "What the Germans Read While Their Classical Writers Wrote," published in 1932, the same time Benjamin was publishing the serialized letters that would become Deutsche Menschen. As Sabine Schiller-Lerg notes, this text appeared against the background of the anniversary of Goethe's death. ${ }^{33}$ It also reflects Benjamin's specific interest in popular (»Kolportage«) literature. In a short essay about this radio play, Benjamin notes the convergence of popular literature of the past and popularization through radio in the present. $\mathrm{He}$ playfully juxtaposes popular and classical forms and flaunts the divide between ordinary life and the formal study of literature. In a way that confirms contemporary scholars who view him as an early exponent of what would become cultural studies, Benjamin offers his radio play as a contribution to the sociology of the public. Such was Benjamin's stated goal for the publication of Deutsche Menschen: it was to be a popular and widely-circulated book.

Though its topic overlaps with Deutsche Menschen, the genre and tone of "Was die Deutschen lasen" are completely different. The Enlightenment brought "justice and equity» (»Recht und Billigkeit»), but, jokes the narrator (playing on

33 Sabine Schiller-Lerg: Walter Benjamin und der Rundfunk. Programmarbeit zwischen Theorie und Praxis, München (K. G. Saur) 1984, p. 233. (See her discussion of Benjamin's reflection on time and technology, p. 242). 
the meaning of Billigkeit as "inexpensiveness"), "the books of your friends are pretty expensive" (GS IV, 643). The characters in the play include a pastor, literary figures, a publisher, and voices of the Enlightenment, Romanticism, and the 19th century, and they playfully discuss popular literature, newspapers, the Bible, and many authors, including Rousseau, Jean Paul, Lavater, and Kant (659-662). When the pastor laments the commercial trivialization of the Bible, the author Karl Philipp Moritz laments that the "better public« and the "simple people« both read low-quality works (647). Yet the discussion also warns that knowledge without humor risks obscurantism, dogmatism, and despotism (655).

Benjamin's point is not only that the Germans read popular literature while their classical authors wrote; he also paints a picture of Germany at the time as relatively quiet and absorbed in local culture. While industrial and political changes swept other countries, this was a time when Germany slept a "healthy, refreshing« sleep (658). Ordinary life and letters from this period reinforce the image of Biedermeier Germany as a place of modesty and decency.

How this ordinary life relates to the classics themselves is a critical issue. One character, a pastor, mentions how wide distribution of newspapers and other print media has led to the availability of Schiller and Goethe even to "Bürgerstochter," while a bookseller notes that the public doesn't read authors like Schiller and Goethe from a lending library $(653 ; 667)$. At the same time, texts later considered to be definitive of the era, like Kant's book on religion, were censored, and one of the characters recommends Indianer in England by the popular dramatist Kotzebue as a way to understand Kant's categorical imperative (651; 666).

In spite of his ranking as a classical author, Goethe emerges here as the rare author whose work appealed to a wide public. References to Goethe run through the play, which ends by vindicating his work in terms of popularity as well as quality. The speaker and the voice of the 19th century conclude by celebrating Goethe's legacy, vying humorously with each other to explain his greatness. The play concludes with the same quotation from Goethe's letter, about the speed of modern life and the decline of the past epoch, that begins Deutsche Menschen (669-670). If this quotation expresses a melancholic or nostalgic tone in Deutsche Menschen, here it concludes a playful entertainment and serves mainly as a tribute to Goethe's lasting appeal for a radio audience observing the centenary of his death.

In his essay on this radio play, Benjamin relates the popularization of literature to new times and technologies, including radio. He describes his goal as raising "scientific questions" about how literature was understood rather than to affirm great works - (»nicht die Literatur, sondern das Literaturgespräch jener Tage, (673). As with Deutsche Menschen, this discussion has close ties to Benjamin's interest in literary scholarship, including the "so-called sociology of the public" (ibid.). No classic can or should be read in isolation from its popular context, suggests 
Benjamin. In the radio play and Deutsche Menschen alike, the values and practices of ordinary people provide the sort of context that dignifies the work of genuinely great writers like Goethe.

Benjamin also compared the mass medium of newspapers to literature. In a 1934 fragment titled "The Newspaper", Benjamin observes that newspapers are the showplace of the day's cultural confusion and antinomies (GS II, 628). Through the impatience of readers and the constant production of news, a dialectical moment emerges, and the difference between author and public begins to disappear: the readers become co-workers with the writers and editors. The newspaper thus performs the "literarization of life relationships" as it displays unresolved antinomies and the depreciation of language (629). Written around the time of similar observations about modern culture made in One-Way Street, this fragment reveals Benjamin's fascination with the potential of mass culture to engage audiences. The reversal of agency between author and reader made possible by the newspaper raises the possibility that other media, including the radio play and the popular collection of letters, can engage the public in meaningful reflection on life and literature.

Like the fragment on newspapers and Deutsche Menschen, Benjamin's radio play demonstrates Benjamin's interest in Goethe and the "classic" period around him in relationship to his own time. With a very different genre and tone, and often the very same quotations, Benjamin displays his abiding interest not just in German letters as such but in reading them against the grain of classicizing, canonical approaches, in broader cultural and historical contexts. The lightness and humor of Benjamin's radio text, which can also be seen in parts of Deutsche Menschen, should help to dismantle any tendency toward a "lachrymose« reading of the Holtz text, for the values it avows are always qualified: "From Honor without Fame/ From Greatness without Glamor/ From Dignity without Pay« (emphasis added). These values suggest an aesthetic not of grandiosity and fame but of modesty, good humor, and ordinary life, not to mention a love for detail and whimsy - hence the Biedermeyer and the jokes in "Was die Deutschen lasen."

\section{"From Cosmopolitans to Bourgeoisie«}

Like the radio play "Was die Deutschen lasen« and Deutsche Menschen, this text, which appeared in the journal Die Literarische Welt in 1932 and was co-authored by editor Willy Haas, gives Goethe pride of place and quotes the familiar passage, cited above, on the acceleration of time and the end of the era (GS IV, 859)..$^{34}$

34 Cf. the 1926 encyclopedia article on Goethe in GS II, 705-739, which, though it doesn't quote this letter, addresses class issues (717-718). The article was intended for a Soviet encyclopedia. 
Here as in the other texts the topic is literary history in relation to the middle class and contemporary culture. Like Deutsche Menschen, the text cites Lukacs' observation that the German middle class had not yet overcome feudalism when the proletariat arose $(851 ; 221)$. While much more concerned with political, economic, and social history than the others texts, this essay deals directly with the theme of cosmopolitanism and its lack in "Was die Deutschen lasen.« It is unclear how much of the design and aim of this text is Benjamin's, but the following statement about the design and approach taken in the text reflects ideas familiar from Deutsche Menschen. Noting the tendency of "so-called historians" to present arbitrary interpretations or even to falsify history, the text goes on to insist on the importance of reading original documents, especially literature, in order to understand how ideals and material realities coincided in the past (817). With its primary interest in economic class history and culture, the text reads in some ways like later Frankfurt School texts, as a critique of Enlightenment promises of universal reason and equality as it passed into market capitalism, from Weltbürgertum to Großbürgertum.

The text poses an interpretive challenge because of its explicit political and cultural aims. One could read the text as a key to the political and economic subtext of Deutsche Menschen, suggesting that the latter really was a Tarntext with a hidden Marxian attack on fascism. On the other hand, the text's context in a leftist magazine and its co-authorship with that magazine's editor may suggest just the opposite: a compromise between Benjamin's cultural and literary interests and the more political agenda of Die Literarische Welt. Finally, a more complex but more accurate reading would suggest a kind of spectrum of texts and contexts, from the playful radio play and the series of letters in the Frankfurter Zeitung to the explicitly anti-fascist "From Cosmopolitan to Bourgeois" and the implicitly anti-fascist Deutsche Menschen. Differences of genre, audience, publication, and distribution allowed and compelled Benjamin to frame his ideas about Goethe and the emergence of German middle class culture and political economy in several different ways. What holds them together, initially, is the insistence that literary and political analysis belong together, and together these texts form a body of work less miscellaneous that it first appears to be, offering a sustained reflection on German political culture at a time of violent transformation.

\section{Conclusion: Farewell, Return, and the Question of the Canon}

The letter Benjamin withdrew from the collection at the last minute comes from a dispute between Friedrich Schlegel and Schleiermacher. Benjamin's introduction to the letter echoes the book's epigraphical affirmation of "greatness without glory« (von Größe ohne Glanz): »It would give a superficial picture of the attitude 
which this series of letters is intended to evoke if they presented only the lustrous side (Glanze) of friendship" (SW III, 219). Schlegel's angry letter responds to Schleiermacher's critical response to Schlegel's Ideen and accuses his friend of lacking "understanding and love in individual matters" (ibid.). Benjamin's decision to cut the letter for its negative tone and lack of weightiness remains unclear, but it placed added emphasis on the letter from Overbeck to Nietzsche that took its place at the end.

Overbeck's letter illustrates his character, theology, and emphatic (even financial) support for the author of Thus Spoke Zarathustra. Benjamin points out that Overbeck's uncompromising views of Christianity cost him a position as theologian in Germany. The letter demonstrates the surprisingly close relationship between a devout Christian theologian and Nietzsche, but it also emphasizes how the "writer and addressee had freely banished themselves from the Germany of the Gründerzeit« (228).

The excised letter from Schlegel to Schleiermacher concludes with a personal, angry farewell, while Overbeck's letter to Nietzsche represents a friendship that survives exile from Germany. Writing just over fifty years later from his own exile, Benjamin may have preferred this ending to the Schlegel letter for its testimony to this »representative of an insightful posterity [»Nachwelt"] (ibid.). The angry tone of Schlegel's letter is replaced by an exemplar of mutual respect between deeply different friends, both of whom have no place in the Germany of their day. If Benjamin's placement of this letter makes it more emphatic, it may represent a "secret Germany« as a kind of Germany not so much lost, as Goethe's quotation suggests, as forced into exile.

To celebrate German values without German territory should have struck German nationalists, particularly in the 1930s, as strange. Such survival in exile sounds much more like Jewish tradition! My point here is not that Benjamin has transposed German into Jewish values but rather that Deutsche Menschen imagines a Germany where values vastly different from National Socialism survive. Neither esoteric nor widely read, Deutsche Menschen affirmed tradition by re-appropriating it and may represent Benjamin's most masterful achievement in the method of quotation he attempted in the Arcades Project. Built of text and commentary, Benjamin's Jewish ark provided a refuge for German values designed to withstand the flood of fascism. The decency, integrity, and modesty of these German letter writers provide a necessary recognition of conflict but also extend hope for its resolution. Writing in 1936, Benjamin could hardly conceptualize political resolution much less forgiveness for the German perpetrators of murder, but the book clearly affirms the possibility and hope for the survival of German values beyond their day.

The same pattern, of course, appears in the Flood story of Genesis: the flood destroys nearly everything, but the ark and its inhabitants, and more importantly, 
the divine-human bond, survive. The design of Benjamin's literary ark and its biblical prototype is thus crucial - even the laconic biblical account accords it a high level of detail. Though he knew that books were not safe from the danger of Nazi destruction, Benjamin, the self-described "last European, " presented his book as such an ark. What it was that he thought could survive the flood was not clear. To return to the analogy with the last letter, the flood removes the tradition from its land and preserves it in a moveable technology: the ark or the book. What is remarkable for Benjamin, writing in 1936, is that his analogy to the flood story implies not only destruction but restoration, a restoration that he would neither describe nor live to see.

Though its publication and distribution did not live up to Benjamin's grandiose hopes, Deutsche Menschen convinced readers as diverse as Scholem and Adorno that it succeeded. Comparing the volume to Benjamin's childhood memoir, Berliner Kindheit um 1900, Adorno applauds the text's attention to the issue of class and observes that the decline of the Bürgertum matches the decline of letterwriting ("Letter from Adorno to Benjamin, 7 November 1936«, quoted in: GS IV, 949). Scholem took the personal dedication as a key to read the book as a Jewish refuge, while Adorno read the book's bold epigraph as a statement of materialist commitment. The book certainly does succeed in naming values worth fighting for, values illustrated but not limited by the German men and women it presents. Whether it succeeds in showing how to fight for those values is still an open question.

There is no need to choose between reading Deutsche Menschen in German or Jewish terms. If Benjamin's dedications to Deutsche Menschen reveal a secret affirmation of Jewish identity, that identity has much in common with the German humanism the collection affirms. What these Jewish and German literary identities share is a model of tradition constituted largely by text and commentary, which is exactly what Benjamin offers. From their initial design to their publication in the Frankfurter Zeitung and later as a pseudonymous book in 1936, Benjamin left a long trail of texts and commentaries, including the dedications to his friends, that would guide the reception of Deutsche Menschen.

But while the letters and their accompanying commentaries appear at first to valorize classic writers and their texts, they are in fact guided affirmations of threatened cultural values. In the end, Benjamin's collection of letters engages multiple contemporary discussions and contexts - literary studies, journalism, politics, social identities, and aesthetics. Far from an esoteric, sectarian affirmation of Jewish identity and tradition, Deutsche Menschen encompasses Jewish and German (or German-Jewish) values through a skillful engagement with traditional texts. The paradox of a Jewish ark rescuing German values is less sentimental than ironic, a disarming recognition of the fact that both »identities s share a biblical tradition filled with stories of exile, power reversal, and writing as a tool for survival. After 
the Holocaust, this recognition may seem naïve, even outrageous, but the texts and readings of Deutsche Menschen confront questions of identity and value that remain open to this day. 